\title{
Penerapan Metode Extreme Programming Pada E-Voting Pemilihan Ketua Unit Kegiatan Mahasiswa (UKM) Sekolah Tinggi Teknologi XYZ
}

\author{
Alfis Arif ${ }^{\mathrm{a} 1}$ \\ ${ }^{a}$ Sekolah Tinggi Teknologi Pagar Alam \\ JL. Simpang Bacang No.43, Karang Dalo, Dempo Tengah, Kota Pagar Alam, Sumatera Selatan 31521 \\ 1 alfisariflyahoo.com
}

\begin{abstract}
Abstrak
Tujuan penelitian ini adalah menerapkan metode Extreme Programming pada sistem E-Voting pemilihan ketua unit kegiatan mahasiswa (UKM) pada Sekolah Tinggi XYZ. Berdasarkan hasil observasi bahwa Pemilihan ketua unit kegiatan mahasiswa (UKM) masih dilakukan secara konvesional yaitu masih menggunakan kertas dalam pencoblosan sehingga kurang efektif dan efesien baik dalam hal waktu, biaya dan tenaga. Sehingga perlu adanya ketersediaan sistem pendukung pada pemilihan unit kegiatan mahasiswa (UKM) Sekolah Tinggi Sekolah Tinggi XYZ agar proses pemilihan ketua unit kegiatan mahasiswa (UKM) menjadi lebih efektif dan efisien. Metode pengembangan sistem yang digunakan yaitu Extreme Programming yang terdiri dari Planning, Design, Coding, dan Testing. Sedangkan aplikasi yang digunakan untuk merancang sistem yaitu Axure Pro, bahasa pemrograman PHP dan database MySQL. Berdasarkan hasil pengujian sistem dengan menggunakan Black Box Testing didapatkan bahwa sistem E-Voting secara fungsional menghasilkan pengujian sesuai yang diharapkan (berhasil) yaitu dengan melakukan pengujian terhadap halaman admin dan halaman mahasiswa dari fungsi View, Input, Edit, Delete dan Print data berhasil dilakukan.
\end{abstract}

Kata kunci: $E$-voting, unit kegiatan mahasiswa (UKM), PHP

\section{Applyed Of Extreme Programming Method For E-Voting Selection Of The Chairman Of Student Unit Activities (UKM) Sekolah Tinggi Teknologi XYZ}

\begin{abstract}
The purpose of this study is to apply the Extreme Programming method in the E-Voting system for the selection of student activity unit heads (UKM) at the Sekolah Tinggi Teknologi Pagar Alam (STTP). Based on observations that the election of the head of the student activity unit (UKM) is still carried out conventionally that is still using paper in voting so it is less effective and efficient both in terms of time, cost, and energy. So it is necessary to have the availability of a support system in the selection of student activity units (UKM) of the Sekolah Tinggi Teknologi Pagar Alam (STTP) so that the process of selecting the chair of student activity units (UKM) becomes more effective and efficient. The system development method used is Extreme Programming which consists of Planning, Design, Coding, and Testing. While the applications used to design the system are Axure Pro, PHP programming language, and MySQL database. Based on the results of system testing using Black Box Testing, it was found that the E-Voting system functionally produced the tests as expected (valid), namely by testing the admin pages and student pages of the View, Input, Edit, Delete and Print data functions successfully.
\end{abstract}

Keywords: E-voting, student activity unit (UKM), PHP

\section{Pendahuluan}

Berdasarkan Undang-Undang Nomor 12 Tahun 2003, bahwa pemilihan umum merupakan sarana untuk mewujudkan kedaulatan rakyat dalam pemerintahan Negara Kesatuan Replubik Indonesia yang berdasarkan Pancasila, sebagaimana diamanatkan dalam UndangUndang Dasar Negara Republik Indonesia Tahun 1945.
Pemilihan umum dapat diartikan juga proses pengisian jabatan-jabatan seperti ketua Himpunan Mahasiswa Jurusan (HMJ), ketua Badan Eksekutif Mahasiswa (BEM), dan sebagainya [1].

Pemungutan suara (voting) merupakan suatu kegiatan pemilihan umum yang dilakukan dimana saja dan di seluruh Negara, sehingga perlu dibudayakan sistem pemungutan suara dengan baik untuk kegiatan pemilihan 
suara. Voting telah menjadi salah satu metode untuk mengambil keputusan penting dalam kehidupan manusia. Voting digunakan mulai dari tingkat masyarakat terkecil, yaitu keluarga, kampus, sampai dengan sebuah negara. Voting digunakan untuk menghimpun aspirasi dari seluruh elemen masyarakat, dan kemudian menemukan jalan keluar yang dianggap paling baik untuk menyelesaikan permasalahan. Dalam sebuah negara yang menganut sistem politik demokrasi, voting digunakan untuk mengambil keputusan negara yang sangat krusial, antara lain adalah untuk memilih wakil-wakil rakyat, atau untuk memilih pemimpin negara yang baru. Oleh karena itu, voting membutuhkan prosedur pelaksanaan yang dapat menjamin kerahasiaan dan keabsahan dari hasil pelaksanaan voting tersebut [2].

Penggunaan teknologi komputer pada pelaksanaan voting ini dikenal dengan istilah electronic voting atau lazim disebut E-Voting. E-voting adalah pengambilan suara dengan menggunakan media elektronik atau perangkat elektronik, the council of Europe $(\mathrm{CoE})$, mendefinisikan sebagai sebuah perangkat pemberian suara secara elektronik sehingga memiliki kemampuan untuk mempercepat tabulasi data, menekan biaya pemilihan dan memiliki kontribusi untuk mencegah pemilih yang tidak berhak. [3]. Melalui sistem $e$-voting, penggunaan kertas dapat ditekan sesedikit mungkin. Sistem $e$-voting dapat dilihat sebagai "proses bisnis" dari rangkaian proses pemilihan umum, dan diharapkan dapat menekan penggunaan kertas dalam pemungutan suara [4].

Pemungutan suara (voting) adalah salah satu tahap pemilihan umum yang di laksanakan pada di setiap negara, hal ini termasuk pada Sekolah Tinggi Teknologi XYZ di Kota Pagar Alam, Sumatera Selatan. Pemungutan suara yang di laksanakan di Sekolah Tinggi Teknologi XYZ ada memiliki bermacam - macam jenisnya, misalnya seperti pemilihan calon Ketua Badan Eksekutif Mahasiswa (BEM), Himpunan Mahasiswa Teknik Informatika (HMTI), Himpunan Mahasiswa Teknik Sipil (HMTS) [5].

Berdasarkan hasil observasi dan wawancara pada didapatkan bahwa sistem yang berjalan saat ini masih menggunakan sistem konvesional yaitu saat pelaksanaan pemilihan ketua Unit Kegiatan Mahasiswa (UKM) dimana panitia memberikan kertas yang berisikan calon-calon ketua Unit Kegiatan Mahasiswa (UKM) kepada mahasiswa, kemudian mahasiswa melakukan pencoblosan calon ketua Unit Kegiatan Mahasiswa (UKM) ditempat yang telah disediakan oleh panitia. Saat perhitungan suara pun perlu memerlukan waktu yang lama dan masih menghasilkan data perhitungan suara yang kurang akurat sehingga hasil yang didapat belum maksimal, maka perlunya suatu sistem E-Voting untuk pemilihan ketua UKM yang memudahkan mahasiswa melakukan voting serta dapat menghitung hasil perolehan suara dengan cepat dan akurat dalam pemilihan ketua UKM.

Berdasarkan pembahasan diatas maka disimpulkan bahwa perlunya sistem E-Voting berbasis Web ini untuk memudahkan proses dalam melakukan pemilihan Ketua UKM pada Sekolah Tinggi Teknologi XYZ.

\section{Metode PENELITIAN}

\section{A. Metode Pengumpulan Data}

Metode - metode yang digunakan peneliti dalam melakukan pengumpulan data adalah sebagai berikut :

1) Teknik Observasi

Teknik Observasi merupakan pelaksanaan pengamatan secara langsung terhadap fenomenafenomena yang berkaitan dengan fokus penelitian.[6].

2) Teknik Wawancara

Melakukan tanya jawab secara langsung pada narasumber yang bersangkutan.

3) Dokumentasi

Penelitian dilakukan menggunakan data yang telah di peroleh atau menggunakan arsip maupun yang lainya.

4) Teknik Studi Pustaka

Data yang diambil dari teori-teori literatur dari buku-buku yang berhubungan dengan objek penelitian sebagai bahan atau dasar pemecahan masalah.

\section{B. Metode Pengembangan Sistem}

Metode pengembangan sistem yang digunakan dalam penelitian ini adalah metode pengembangan sistem Extreme Programming dapat dilihat pada gambar 1. Extreme Programming adalah sebuah pendekatan atau model pengembangan perangkat lunak yang mencoba menyederhanakan berbagai tahapan dalam proses pengembangan tersebut sehingga menjadi lebih adaptif dan fleksibel [7].

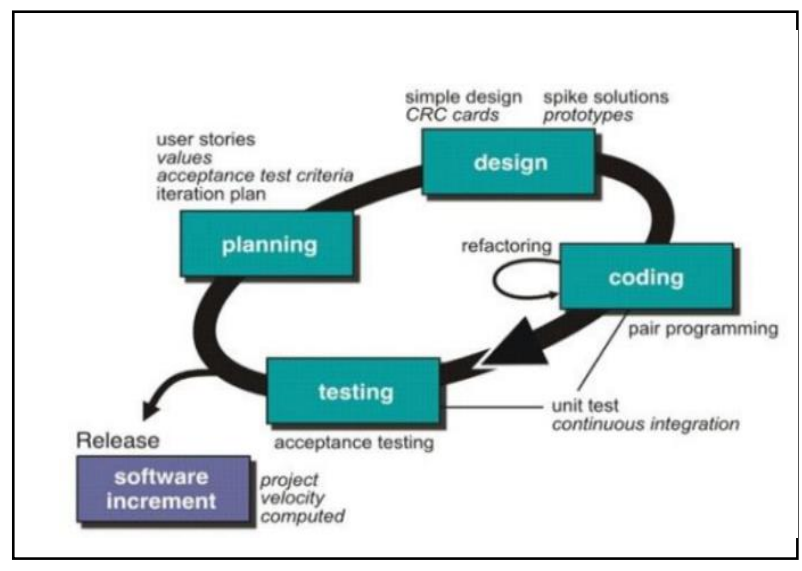

Gambar 1. Metode Extreme Programming

Tahapan metode Extreme Programming [8]:

1) Planning

Pada bagian planning ini dilakukan perencanaan pembuatan E-Voting untuk pemilihan ketua unit kegiatan mahasiswa (UKM) dengan database MySql dan bahasa pemrograman PHP sebagai database-nya, serta dalam tahap ini peneliti juga menyiapkan keperluan dalam pembangunan sistem E-Voting seperti data yang ada pada Sekolah Tinggi Teknologi XYZ. 
2) Design

Pada bagian ini dilakukan proses perancangan sistem yang akan dibuat oleh peneliti. Perancangan menggunakan Unified Modeling Language (UML) dan perancangan antarmuka yang akan dibuat menggunakan aplikasi axure serta aplikasi dreamweaver.

\section{3) Coding}

Pada bagian ini dilakukan proses penerjemahan dari perancangan ke dalam sebuah bahasa pemrograman, sehingga proses input akan menghasilkan output melalui sebuah sistem yang dibangun.

4) Testing

Pada bagian ini merupakan ujicoba dari sistem yang dibangun oleh peneliti. Hal ini dilakukan untuk mengetahui sudah terpenuhi atau belum kebutuhan sistem yang dibangun. Dalam testing ini peneliti menggunakan pengujian blackbox testing.

\section{Analisa Masalah}

Analisis masalah saat ini yaitu panitia memberikan kertas pemilihan yang berisikan calon-calon ketua UKM kepada mahasiswa yang melakukan voting kemudian mahasiswa melakukan pencoblosan dan saat melakukan perhitungan suara mahasiswa dan panitia berkumpul untuk menghitung hasil dari pemilihan seperti gambar 2 . berikut ini:

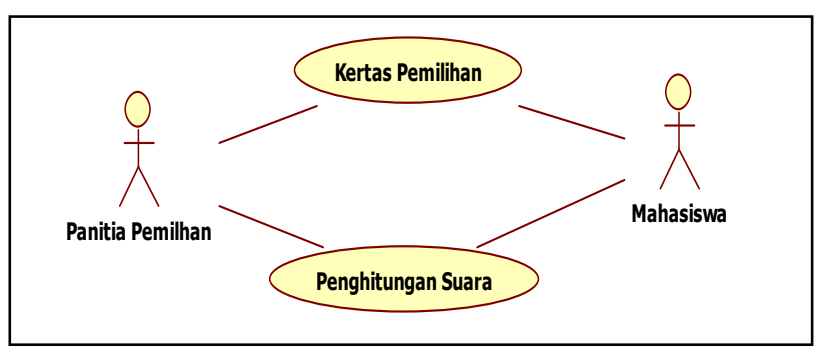

Gambar 2. Usecase Diagram Berjalan

\section{Perancangan Sistem}

1) Usecase Diagram

Use case sistem E-Voting pemilihan menggambarkan hubungan antara aktor dan sistem. Dalam usecase dapat diketahui gamabaran secara umum bagaimana sistem yang dibuat, seperti pada gambar 3. Berikut ini:

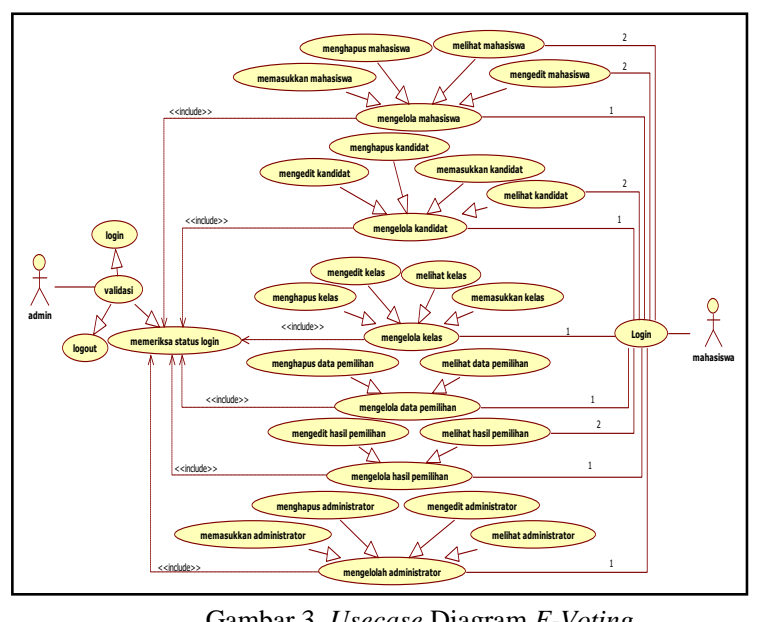

Gambar 3. Usecase Diagram E-Voting

Ket : 1 = Admin, 2 = Mahasiswa

Pada gambar 3. diatas admin dapat mengelolah data-data yang dibutuhkan sistem E-Voting seperti melakukan create, update, delete dan view data dan pengguna yang sebagai pemilih bisa melakukan pemilihan melihat data mahasiswa yang akan melakukan pemilihan dan melihat profil calon kandidat yang mencalonkan diri sebagai ketua Unit Kegiatan Mahasiswa (UKM).

\section{2) Activity Diagram Admin}

Activity diagram admin mengambarkan aktifitas yang dilakukan oleh admin didalam sistem, seperti pada gambar 4. berikut ini.

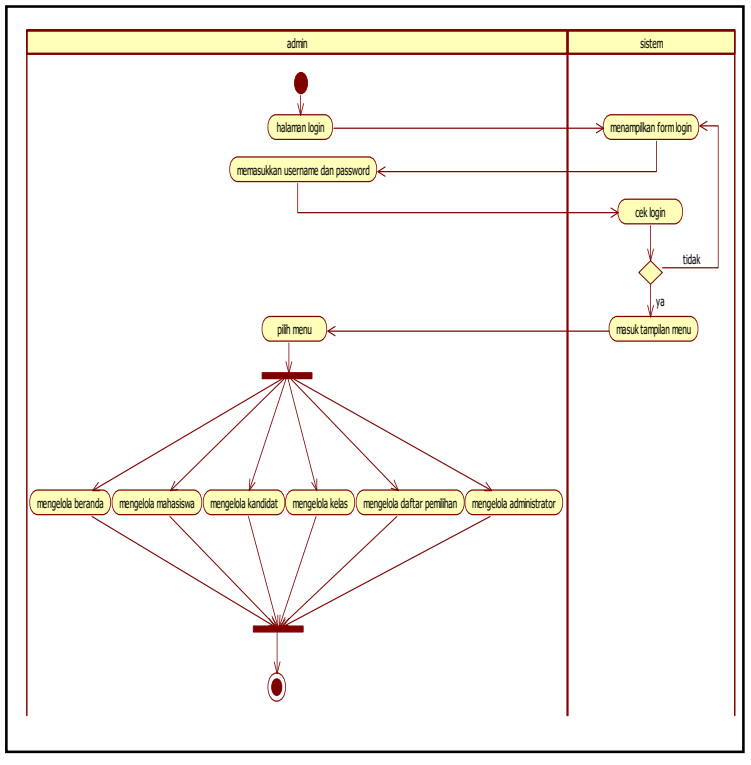

Gambar 4. Activity Diagram Admin

3) Activity Diagram Mahasiswa

Activity diagram mahasiswa menggambarkan aktifitas yang dilakukan mahasiswa didalam sistem, seperti pada gambar 5. berikut : 


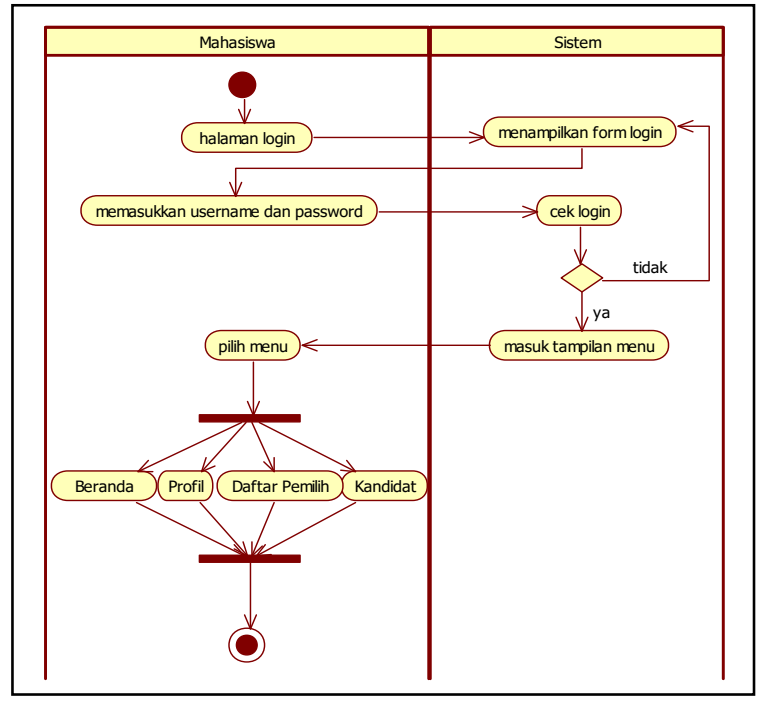

Gambar 5. Activity Diagram Mahasiswa

\section{HASIL DAN PEMBAHASAN}

\section{A. Implementasi Sistem}

Implementasi sistem merupakan implementasi mahasiswa melakukan pemilihan sampai perhitungan hasil pemilihan.

\section{1) Tampilan Mепи Utama}

Menu utama E-Voting pemilihan Unit Kegiatan Mahasiswa (UKM) adalah tampilan utama ketika user memasuki halaman website untuk memilih UKM yang akan melakukan pemilihan. Seperti pada gambar 6 . dibawah ini :

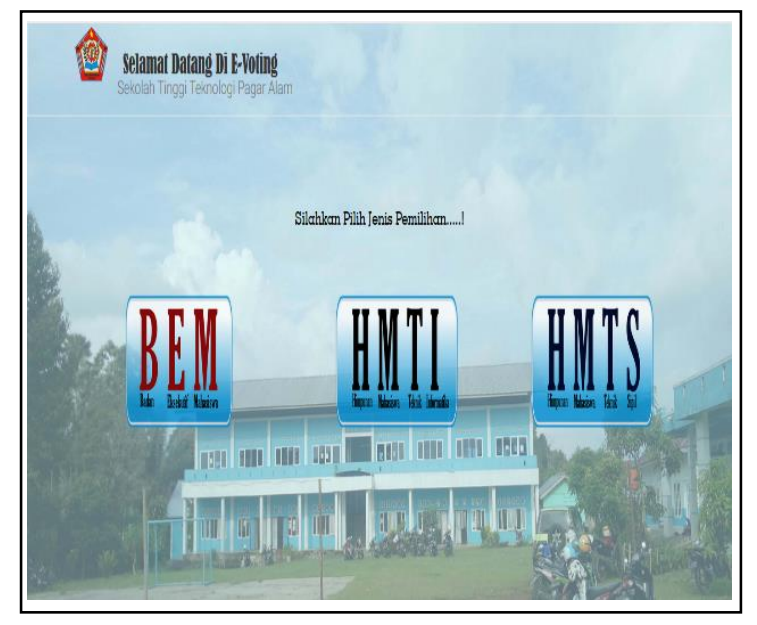

Gambar 6. Halaman Utama

\section{2) Tampilan Login Mahasiswa}

Pada halaman ini mahasiswa mengklik button login mahasiswa untuk masuk ke sistem. Seperti pada gambar 7. dibawah ini :

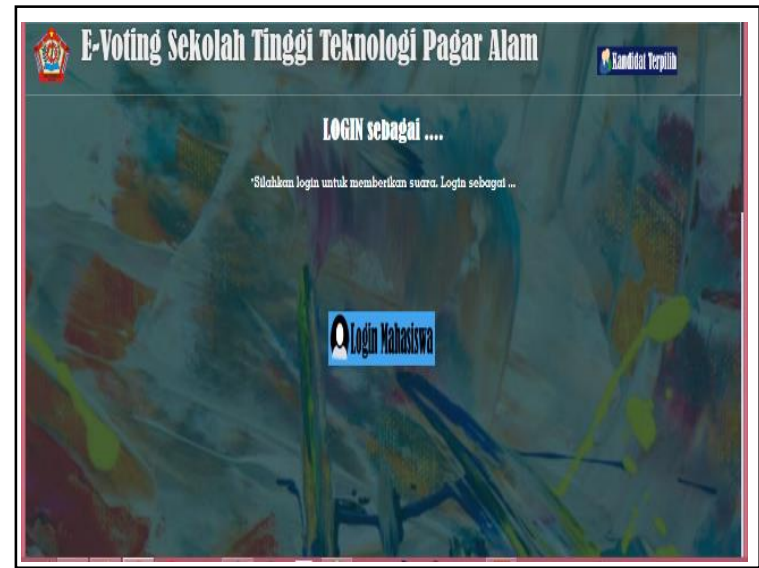

Gambar 7. Halaman Login Mahasiswa

\section{3) Halaman Beranda Mahasiswa}

Halaman beranda mahasiswa ini merupakan halaman mahasiswa setelah melakukan login ke sistem, dihalaman ini mahasiswa dapat langsung memberikan partisipasi suaranya dalam pemilihan ketua UKM. Seperti pada gambar 8. dibawah ini :

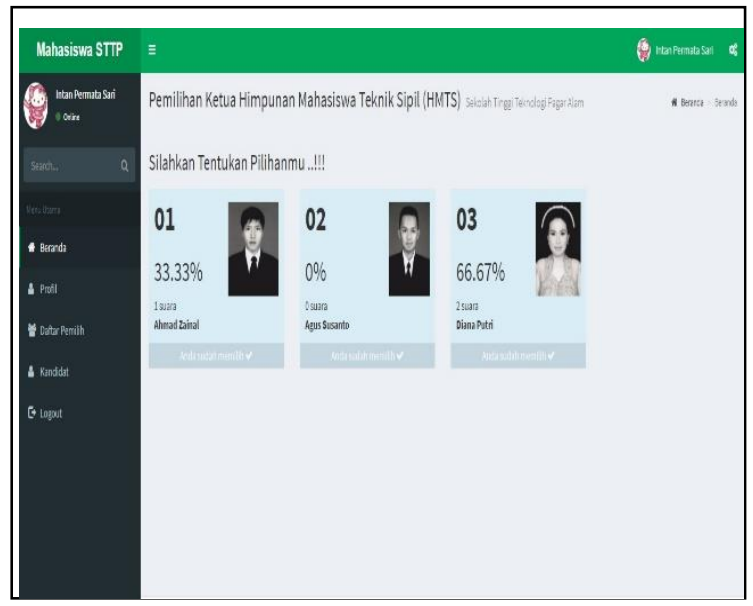

Gambar 8. Halaman Beranda Mahasiswa

\section{4) Halaman Data Pemilih}

Pada halaman ini merupakan halaman data pemilih, mahasiswa dapat melihat data pemilih yang akan melakukan pemilihan. Seperti yang ditunjukkan gambar 9 . berikut ini :

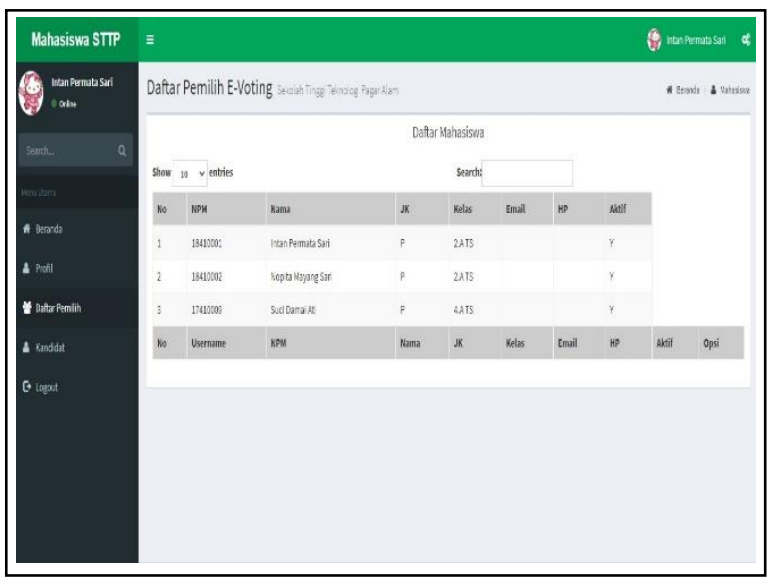

Gambar 9. Halaman Data Pemilih 


\section{5) Halaman Kandidat}

Pada halaman ini dimenu kandidat, mahasiswa dapat melihat profil dari kandidat yang mecalonkan diri sebagai ketua UKM seperti melihat foto, nama, nomor kandidat, visi dan misi. Seperti pada gambar 10. dibawah ini :

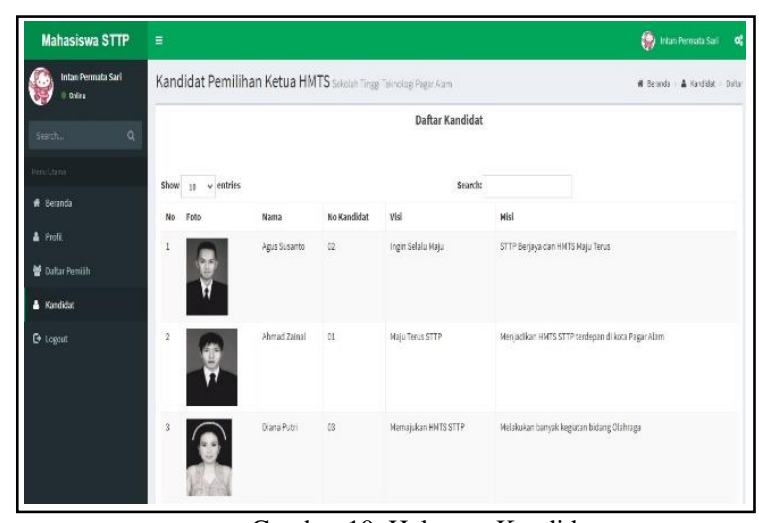

Gambar 10. Halaman Kandidat

\section{6) Halaman Login Admin}

Halaman login admin berfungsi untuk masuk ke sistem E-Voting atau halaman administrator, admin bertugas mengelola data seperti menambahkan, mengubah, menghapus dan melihat data yang akan ditampilkan di $E$ Voting pemilihan UKM. Seperti pada gambar 11. dibawah ini :

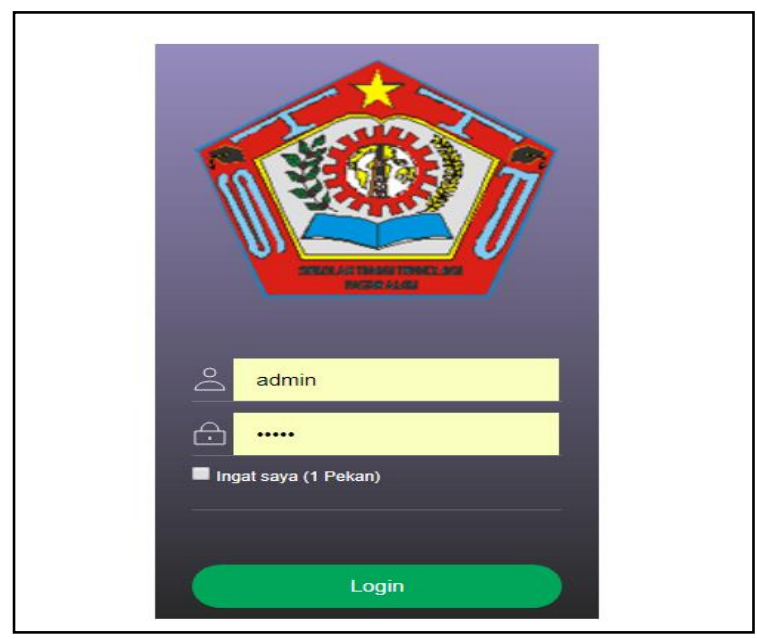

Gambar 11. Login Admin

\section{7) Halaman Beranda Admin}

Halaman beranda admin yaitu halaman setelah admin melakukan login pada sistem E-Voting pemilihan UKM pada Sekolah Tinggi Teknologi XYZ. Seperti gambar 12. ini :

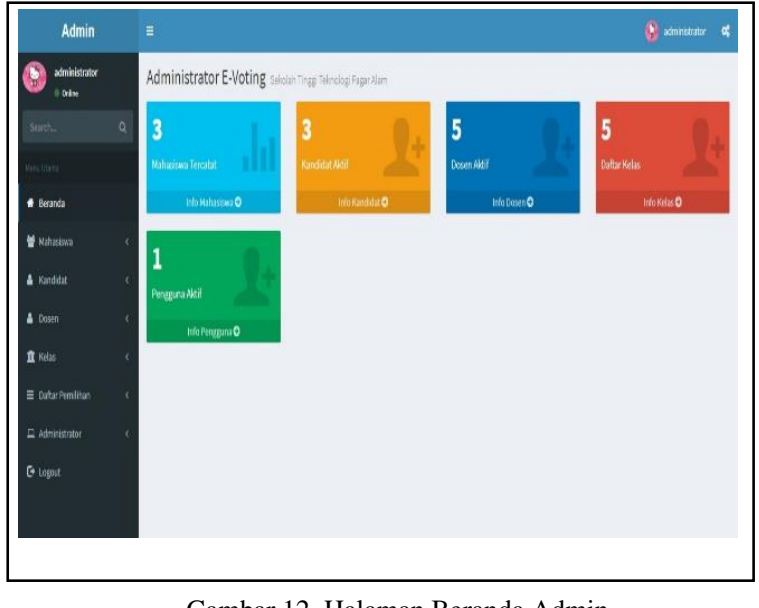

Gambar 12. Halaman Beranda Admin

8) Halaman Data Pemilih

Pada gambar 13. Halaman data pemilihan berfungsi untuk melihat siapa saja yang telah melakukan voting dan hanya admin yang bisa melihat data pemilihan ini.

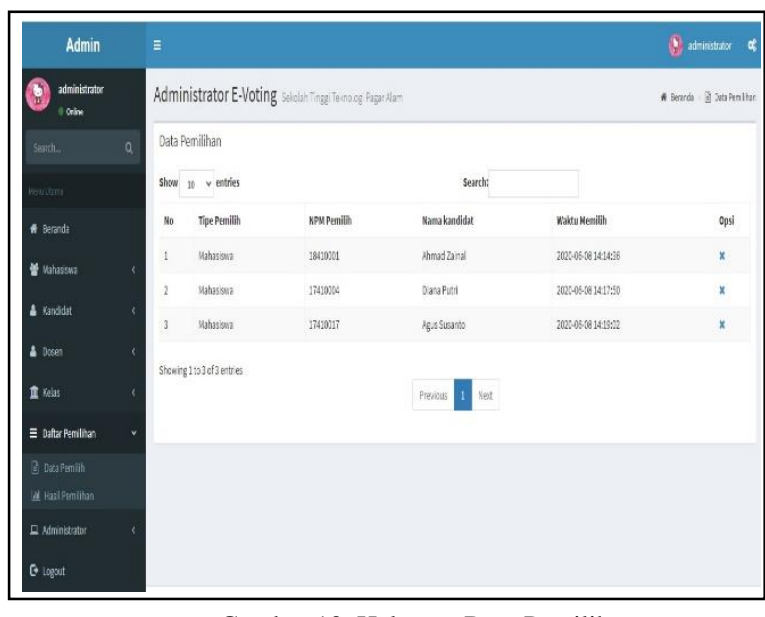

Gambar 13. Halaman Data Pemilih

9) Halaman Hasil Pemilihan

Halaman hasil pemilihan berfungsi untuk melihat jumlah suara yang diperoleh oleh setiap kandidat yang mencalonkan diri sebagai ketua UKM. Seperti gambar 14. dibawah ini :

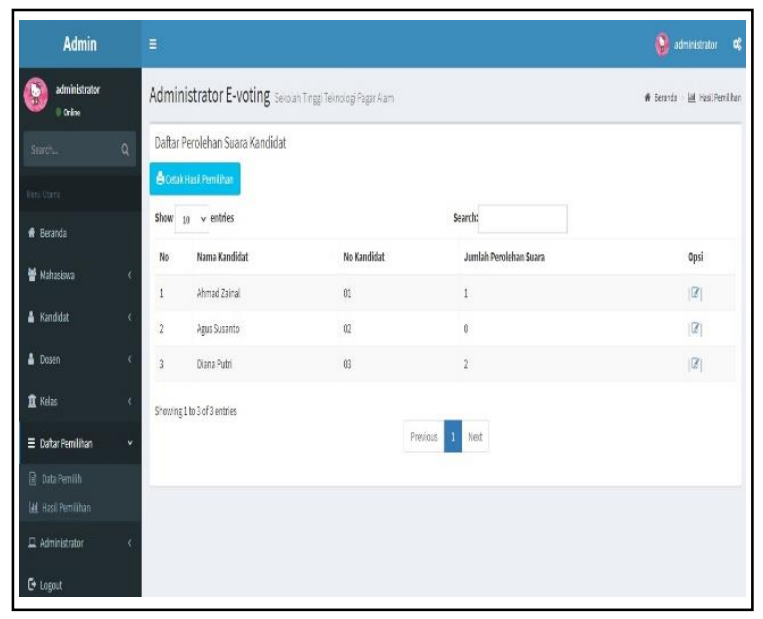

Gambar 14. Halaman Hasil Pemilihan 
Pada halaman hasil pemilihan dapat dilakukan pencetakan / print hasil pemilihan yang dapat dilihat pada gambar 15 . dibawah ini :

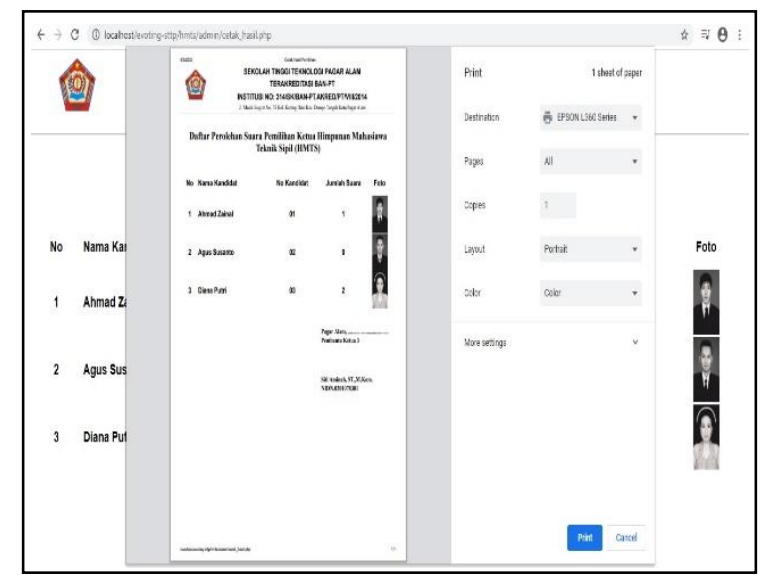

Gambar 15. Print Hasil Pemilihan

\section{B. Pengujian Sistem}

Pengujian menggunakan metode blackbox testing merupakan suatu metode yang hanya menggunakan batas bawah dan batas atas dari data yang dihasilkan [7]. Metode yang digunakan yaitu pengujian untuk mengetahui fungsi-fungsi, masukkan dan keluaran didalam program apakah sudah berjalan sesuai dengan yang diharapkan atau belum [9], pengujian yang dilakukan yaitu:

- Fungsi view, input, edit, print dan delete data.

- Tampilan antar muka/user interface.

- Koneksi dengan database.

Untuk mengetahui hasil dari pengujian, dituangkan dalan suatu tabel hasil pengujian sebagai berikut:

1) Pengujian Halaman Admin

TABEL I

TABEL HASIL PENGUJIAN HALAMAN ADMIN

\begin{tabular}{|c|c|c|c|}
\hline No & $\begin{array}{l}\text { Proses yang } \\
\text { dilakukan }\end{array}$ & Hasil yang diharapkan & $\begin{array}{l}\text { Keteranga } \\
\text { n }\end{array}$ \\
\hline 1. & $\begin{array}{l}\text { Mengetik alamat } \\
\text { website }\end{array}$ & $\begin{array}{l}\text { Menampilkan halaman } \\
\text { utama website dengan } \\
\text { tampilan dan susunan } \\
\text { menu yang diinginkan. }\end{array}$ & Berhasil \\
\hline 2. & $\begin{array}{l}\text { Klik menu "Login } \\
\text { Admin" lalu isi } \\
\text { username dan } \\
\text { password. }\end{array}$ & Menampilkan login & Berhasil \\
\hline 3. & $\begin{array}{l}\text { Klik menu } \\
\text { "Beranda". }\end{array}$ & $\begin{array}{l}\text { Menampilkan informasi } \\
\text { mahasiswa yang } \\
\text { terdaftar, kandidat aktif, } \\
\text { dosen aktif, daftar kelas } \\
\text { dan pengguna aktif. }\end{array}$ & Berhasil \\
\hline \multirow[t]{4}{*}{4.} & \multirow[t]{4}{*}{$\begin{array}{l}\text { Klik menu } \\
\text { "Mahasiswa". }\end{array}$} & $\begin{array}{l}\text { Menampilkan halaman } \\
\text { daftar mahasiswa untuk } \\
\text { admin }\end{array}$ & Berhasil \\
\hline & & $\begin{array}{l}\text { Klik tombol tambah } \\
\text { menampilkan form } \\
\text { tambah daftar } \\
\text { mahasiswa. }\end{array}$ & Berhasil \\
\hline & & $\begin{array}{l}\text { Klik tombol edit } \\
\text { menampilkan form edit } \\
\text { daftar mahasiswa. }\end{array}$ & Berhasil \\
\hline & & $\begin{array}{l}\text { Klik tombol hapus } \\
\text { menghapus daftar }\end{array}$ & Berhasil \\
\hline
\end{tabular}

\begin{tabular}{|c|c|c|c|}
\hline No & $\begin{array}{l}\text { Proses yang } \\
\text { dilakukan }\end{array}$ & Hasil yang diharapkan & $\begin{array}{l}\text { Keteranga } \\
\text { n }\end{array}$ \\
\hline & & mahasiswa. & \\
\hline \multirow[t]{4}{*}{5.} & \multirow[t]{4}{*}{$\begin{array}{l}\text { Klik menu } \\
\text { "Kandidat". }\end{array}$} & $\begin{array}{l}\text { Menampilkan halaman } \\
\text { daftar kandidat untuk } \\
\text { admin }\end{array}$ & Berhasil \\
\hline & & $\begin{array}{l}\text { Klik tombol tambah } \\
\text { menampilkan form } \\
\text { tambah daftar kandidat. }\end{array}$ & Berhasil \\
\hline & & $\begin{array}{l}\text { Klik tombol edit } \\
\text { menampilkan form edit } \\
\text { daftar kandidat. }\end{array}$ & Berhasil \\
\hline & & $\begin{array}{l}\text { Klik tombol hapus } \\
\text { menghapus daftar } \\
\text { kandidat. }\end{array}$ & Berhasil \\
\hline \multirow[t]{4}{*}{6.} & \multirow[t]{4}{*}{$\begin{array}{l}\text { Klik menu } \\
\text { "Kelas". }\end{array}$} & $\begin{array}{l}\text { Menampilkan halaman } \\
\text { daftar kelas untuk admin }\end{array}$ & Berhasil \\
\hline & & $\begin{array}{l}\text { Klik tombol tambah } \\
\text { menampilkan form } \\
\text { tambah daftar kelas. }\end{array}$ & Berhasil \\
\hline & & $\begin{array}{l}\text { Klik tombol edit } \\
\text { menampilkan form edit } \\
\text { daftar kelas. }\end{array}$ & Berhasil \\
\hline & & $\begin{array}{l}\text { Klik tombol hapus } \\
\text { menghapus daftar kelas. }\end{array}$ & Berhasil \\
\hline \multirow[t]{2}{*}{7.} & \multirow[t]{2}{*}{$\begin{array}{l}\text { Klik menu "Data } \\
\text { Pemilihan". }\end{array}$} & $\begin{array}{l}\text { Menampilkan halaman } \\
\text { daftar mahasiswa untuk } \\
\text { admin }\end{array}$ & Berhasil \\
\hline & & $\begin{array}{l}\text { Klik tombol hapus } \\
\text { menghapus data } \\
\text { pemilihan. }\end{array}$ & Berhasil \\
\hline \multirow[t]{3}{*}{8.} & \multirow[t]{3}{*}{$\begin{array}{l}\text { Klik menu "Hasil } \\
\text { Pemilihan". }\end{array}$} & $\begin{array}{l}\text { Menampilkan halaman } \\
\text { hasil pemilihan untuk } \\
\text { admin }\end{array}$ & Berhasil \\
\hline & & $\begin{array}{l}\text { Klik tombol cetak hasil } \\
\text { pemilihan menampilkan } \\
\text { lembar yang akan } \\
\text { dicetak. }\end{array}$ & Berhasil \\
\hline & & $\begin{array}{l}\text { Klik tombol edit } \\
\text { menampilkan form edit } \\
\text { hasil pemilihan. }\end{array}$ & Berhasil \\
\hline \multirow[t]{4}{*}{9.} & \multirow[t]{4}{*}{$\begin{array}{l}\text { Klik menu } \\
\text { "Administrator". }\end{array}$} & $\begin{array}{l}\text { Menampilkan halaman } \\
\text { daftar administrator } \\
\text { untuk admin }\end{array}$ & Berhasil \\
\hline & & $\begin{array}{l}\text { Klik tombol tambah } \\
\text { menampilkan form } \\
\text { tambah daftar } \\
\text { administrator. }\end{array}$ & Berhasil \\
\hline & & $\begin{array}{l}\text { Klik tombol edit } \\
\text { menampilkan form edit } \\
\text { daftar administrator. }\end{array}$ & Berhasil \\
\hline & & $\begin{array}{l}\text { Klik tombol hapus } \\
\text { menghapus daftar } \\
\text { administrator. }\end{array}$ & Berhasil \\
\hline 10. & $\begin{array}{l}\text { Klik } \\
\text { "Logout". }\end{array}$ & $\begin{array}{l}\text { Kembali kehalaman } \\
\text { login. }\end{array}$ & Berhasil \\
\hline
\end{tabular}

2) Pengujian Halaman Mahasiswa

TABEL II

TABEL HASIL PENGUJIAN HALAMAN MAHASISWA

\begin{tabular}{|c|c|c|c|}
\hline No. & $\begin{array}{l}\text { Proses yang } \\
\text { dilakukan }\end{array}$ & Hasil yang diharapkan & Keterangan \\
\hline 1. & $\begin{array}{l}\text { Mengetik alamat } \\
\text { website }\end{array}$ & $\begin{array}{l}\text { Menampilkan halaman } \\
\text { utama website dengan } \\
\text { tampilan dan susunan } \\
\text { menu yang diinginkan. }\end{array}$ & Berhasil \\
\hline 2. & $\begin{array}{l}\text { Klik menu "Login } \\
\text { Mahasiswa" lalu } \\
\text { isi username dan } \\
\text { password. }\end{array}$ & Menampilkan login & Berhasil \\
\hline 3. & $\begin{array}{l}\text { Klik menu } \\
\text { "Beranda". }\end{array}$ & $\begin{array}{l}\text { Menampilkan halaman } \\
\text { untuk melakukan voting. }\end{array}$ & Berhasil \\
\hline
\end{tabular}




\begin{tabular}{|c|l|l|c|}
\hline No. & $\begin{array}{l}\text { Proses yang } \\
\text { dilakukan }\end{array}$ & Hasil yang diharapkan & Keterangan \\
\hline & & $\begin{array}{l}\text { Klik tombol pilihan } \\
\text { anda!! melakukan } \\
\text { voting/memberikan hak } \\
\text { suara. }\end{array}$ & Berhasil \\
\hline $\mathbf{4 .}$ & $\begin{array}{l}\text { Klik "Profil". } \\
\text { " menu }\end{array}$ & $\begin{array}{l}\text { Menampilkan halaman } \\
\text { profil data diri } \\
\text { mahasiswa. }\end{array}$ & Berhasil \\
\cline { 2 - 4 } & $\begin{array}{l}\text { Klik tombol edit } \\
\text { menampilkan form edit } \\
\text { data mahasiswa. }\end{array}$ & Berhasil \\
\hline $\mathbf{5 .}$ & $\begin{array}{l}\text { Klik menu } \\
\text { "Kandidat". }\end{array}$ & $\begin{array}{l}\text { Menampilkan halaman } \\
\text { data kandidat. }\end{array}$ & Berhasil \\
\hline $\mathbf{6 .}$ & $\begin{array}{l}\text { Klik menu } \\
\text { "Logout". }\end{array}$ & $\begin{array}{l}\text { Kembali kehalaman } \\
\text { login. }\end{array}$ & Berhasil \\
\hline
\end{tabular}

Keterangan : Berhasil = Proses yang dilakukan sama dengan hasil yang diharapkan (valid).

Berdasarkan hasil pengujian seperti pada tabel 1. dan tabel 2. menunjukkan bahwa fungsionalitas dari sistem setelah di ujicoba menggunakan Black Box Testing didapatkan Berhasil semua.

\section{KESIMPULAN}

Dari hasil penelitian, analisis, perancangan sistem, pembuatan program sampai penyelesaian penulisan penelitian ini dapat disimpulkan bahwa dengan dibuatnya E-Voting untuk pemilihan ketua unit kegiatan mahasiswa (UKM) pada Sekolah Tinggi Teknologi Pagar Alam ini dapat memudahkan pada saat proses pemilihan dan menghitung hasil pemilihan Unit Kegiatan Mahasiswa (UKM) di Sekolah Tinggi Teknologi XYZ.

\section{DAFTAR PUSTAKA}

[1] Ikhwani, Y., 2018. Analisis Dan Rancangan Sistem EVoting Pemilihan Ketua Osis. Technologia, 09(03), Pp. 138-143.

[2] Arifin, M., 2016. Analisa Dan Perancangan Sistem EVoting Pemilu Raya Bem (Pemira-Bem) Di Universitas Muria Kudus. Surabaya, Jurusan Sistem Informasi Its Dan Association For Information Systems Indonesia Chapter (Aisindo).

[3] Risnanto, S., 2017. Aplikasi Pemungutan Suara Elektronik / E-Voting Menggunakan Teknologi Short Message Service Dan At Command. Jurnal Teknik Informatika, 10(1), Pp. 17-26.

[4] Azwanti, N., 2017. Perancangan E-Voting Berbasis Web. Jurnal Komputer Terapan, 03(2), Pp. 119132.

[5] Lavarino, D., 16. Rancang Bangun E-Voting Berbasis Website Di Universitas Negeri Surabaya. Jurnal Manajemen Informatika, 06(1), Pp. 72-81.

[6] Poluan, C., 2015. Analisis Penerapan Metode Direct Costing Terhadap Penentuan Harga Pokok Produksi Pada Pt. Bangun Wenang Beverage Company. Jurnal Emba, 03(1), Pp. 34-42.

[7] M. Sidi Mustaqbal, R. F. F. A. H. R., 2015. Pengujian Aplikasi Menggunakan Black Box Testing Boundary Value Analysis (Studi Kasus Aplikasi
Prediksi Kelulusan Snmptn). Jurnal Ilmiah Teknologi Terapan (Jitter), 1(3), Pp. 31-36.

[8] Pratama, E. B., 2017. Pendekatan Metodologi Extreme Programming Pada Aplikasi E-Commerce. Jurnal Khatulistiwa Informatika, 5(2), Pp. 92-102.

[9] Shalahuddin, R. A. M., 2014:275. Rekayasa Perangkat Lunak Terstruktur Dan. Bandung: Informatika Bandung. 